\title{
Observations of white-tailed deer and cattle diets in Mexico
}

\author{
ALFONSO MARTINEZ M., VÍCTOR MOLINA, FERNANDO GONZÁLEZ S., JORGE S. MARROQUÍN, AND \\ JESÚS NAVAR CH.
}

Authors are professors, Forestry College, Universidad Autonóma de Nuevo León, Linares 67700. At the time of the research, Molina was an undergraduate student, Forestry College, Universidad Autónoma de Nuevo León. Molina is currently employed by the Asociacion Nacional de Ganaderos Diversificados, Nuevo Laredo Tamaulipas.

\begin{abstract}
Most rangelands in northern Nuevo Leon, Mexico, have been grazed intensely for more than 10 years simultaneously by cattle and white-tailed deer (Odocoileus virginianus texanus). There is a lack of information concerning diet selection of white-tailed deer and cattle in this region. We observed the dietary preferences of these ungulates in northeastern Nuevo Leon for a 6 month period. Two adjacent areas were subjected to rotational grazing (RG) and continuous cattle grazing (CG). Fecal analysis was used to determine dietary overlap of these 2 sympatric ruminants. Cattle diets averaged $70 \%$ grasses, $23 \%$ browse, and $4 \%$ forbs. Deer diets were $63 \%$ browse, $24 \%$ forbs and $12 \%$ grasses in both areas. The preferred species for cattle in both areas were grasses. Deer preferred forbs on the continuous grazed area and grasses on rotational grazed area. Zacate toboso [Hilaria mutica (Buckl.] Benth.) was the most preferred species by both ruminants in both management systems. Differences between cattle and deer diets were significant $(\mathrm{P}<\mathbf{0 . 0 5})$. The similarity index was higher on the rotational grazed $(23 \%)$ than on the continuous grazed area $(15 \%)(P<0.05)$. The higher similarity index in $R G$ area may have been a result of the altered forage preferences of deer. Zacate toboso under RG could be an important feed resource in those areas where white-tailed deer and cattle graze in common.
\end{abstract}

Key Words: cevrides, livestock, forage preferences, grazing methods, tobosa grass

During the past decade the use of rotational grazing (RG) has increased in northeastern Mexico. Some of this area has been grazed intensely with cattle (Bos taurus, Bos indicus) and whitetailed deer (Odocoileus virginianus texanus) during this period. Under rotational grazing it is common that a single herd of livestock rotates rapidly through several relatively small pastures. Grazing periods typically last 1-5 days, with rest periods of 30-60 days (Savory and Parsons 1980), depending on the rate of plant growth. Intensive management of deer requires a thorough understanding of the effects of different grazing methods such as rotational grazing. Cohen et al. (1989a, 1989b) compared the effects of rotational grazing and continuous yearlong grazing (CG) on home ranges, movement indices of female white-tailed

Research was funded by the Asociación Nacional de Ganaderos Diversificados. Manuscript accepted 28 May 1996. deer, and forage availability in the Coastal Bend region of Texas. Many studies have been conducted on the food habits of whitetailed deer and cattle in South Texas (Davis and Winkler 1968; Chamrad and Box 1968; Drawe 1968; Everitt and Drawe 1974; Arnold and Drawe 1979). Quintanilla (1989) studied the dietary preferences of white-tailed deer in North Nuevo Leon, Mexico. Few investigations have examined diets of cattle in common with deer for different grazing methods. In northeastern Mexico, no study has been conducted of diet overlap between cattle and white-tailed deer.

The objectives of the study were to determine the botanical composition of cattle and deer diets and to observe differences in dietary overlap of both ruminants between rotational grazing and continuous grazing.

\section{Materials and Methods}

The study was conducted on 2 adjacent ranches located on the Rio Grande Plains in Anahuac, Nuevo Leon, Mexico, at an elevation of $150 \mathrm{~m}$, approximately $89 \mathrm{~km}$ south from Nuevo Laredo, Tamaulipas. The annual average precipitation is $55 \mathrm{~cm}$. Average daily temperature is $15^{\circ} \mathrm{C}$. Four soil types are present but the principal soil of the 2 ranches is a sandy loam type. The chaparral-mixed grass community contains moderately dense stands of mixed shrub species including chaparro prieto [Acacia rigidula, Benth], mesquite [Prosopis glandulosa, Torr.], huizache [Acacia farnensiana, (L.) Willd.], granjeno [Celtis pallida, Torr.], cenizo [Leucophyllum frutescens (Berl.) Johnst.] and nopal [Opuntia spp.]. Dominant herbaceous plants are zacate Buffel [Cenchrus ciliaris, L.], zacate toboso [Hilaria mutica, (Buckl.) Benth], saladilla [Varilla texana, Gray], and croton [Croton leucophyllus, Muell.].

The rotational grazing method was implemented 8 years prior to the study by subdividing a 3,100 ha ranch into 64 equal sized paddocks. Each paddock was grazed from 3 to 6 days and rested 32 to 47 days, depending on vegetation response. The rotational grazing area was stocked at a rate of $3.1 \mathrm{ha} / \mathrm{AUY}$. The continuous grazing area was a 3,300-ha ranch stocked at a rate of 10 ha/AUY.

Botanical composition of diets was determined monthly by microscopic examination of fresh fecal material period (Sparks 
and Malechek 1968) during a 6 month period. Fecal samples from deer in the rotational grazed area collected from 19 belt transects $(300 \mathrm{~m} \times 4 \mathrm{~m})$ and from 10 belt transects in the continuous grazed area using $300 \mathrm{~m} \times 4 \mathrm{~m}$ (19 in the RG; 10 in CG). Cattle fecal samples were collected using 4 animals randomly selected at the beginning of the study. Each analyzed sample was a composite of feces collected by animal during a 5 day period.

Botanical composition of the experimental pastures was determined monthly utilizing the line intercept method (Canfield 1941). The percentage of foliar cover of grasses, shrubs, and forbs was $41 \%, 42 \%$, and $16 \%$ in the rotational grazed area and $25 \%, 67 \%$, and $6 \%$ in the continuous grazed area. Dietary similarities were calculated using Kulczynski's formula (Oosting 1956) in which

$$
\text { Similarity index }=\frac{2 \mathrm{w}}{(\mathrm{a}+\mathrm{b})} * 100,
$$

where $w$ is the smaller percentage of 1 plant species in the diet of 2 different animal species and $(a+b)$ is the sum of the 2 percentages of intake of 1 plant species. Similarity indices were separated by a standard t-test.

Preference indices were calculated by a ratio described by Taylor et al. (1980):

$\mathrm{PR}=(\%$ in the diet $-\%$ in standing crop $) /(\%$ in the diet $+\%$ in standing crop).

Data were analyzed as a completely randomized design. One ANOVA model with crossed factor was used to examine the differences in the diet composition of both ruminant species. Student's $t$ was used to detect differences $(P<0.05)$.

\section{Results}

\section{Species Composition of Cattle Diets}

Thirty-four plant species were identified in the fecal samples of cattle. Two species were not identified. Species composition of cattle diets are shown by grazing method areas in Table 1 the mean diet of cattle in both areas was grasses $71 \%$, shrubs 235 , and forbs $4 \%$. In average grasses, shrubs, and forbs formed $71 \%$, $23 \%$, and $4 \%$. (Fig. 1). In the rotational grazing area the diet of cattle was formed for 33 plant species. The principal grasses consumed were zacate buffel (22\%), zacate toboso (17\%), and panizo texano [Panicum texanum, Buckl.] (14\%). Shrubs were the second most abundant class of plants in the diet of cattle $(16 \%)$ and the major species were nopal (8\%), brazil [Condalia hookeri, M.C. Johnst.] (2\%), escobilla butterfly-bush [Buddieia scorioides, H.B.K.] (2\%), and granjeno (1\%). Forbs composed only $4 \%$ of the diet.

In the continuous grazed area, cattle diets were higher in shrubs and lower in grasses and forbs than in rotational grazed area (Fig. 1). The diversity in the diet of cattle was lower in the continuous grazed areas ( 29 species). Grasses were the dominant component in the diet $(67 \%)$. The major species were zacate buffel $(17 \%)$, zacate toboso (14\%), and panizo texano (13\%). Shrubs were consumed at a relatively high average $(27 \%)$. The most important

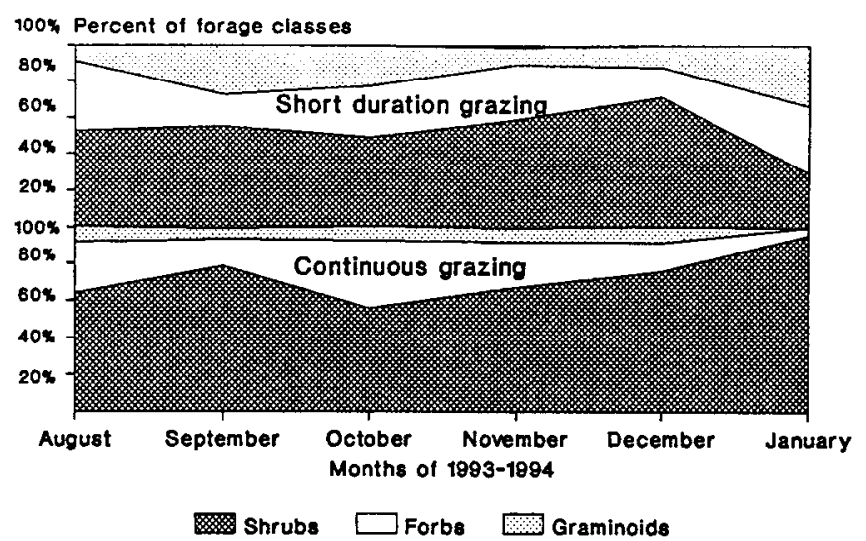

Fig. 1. Percent of forage classes in the diet of cattle in a rotationally grazed and a continuously grazed area.

shrubs species were nopal (17\%), cenizo (4\%), guajillo (2\%), and escobilla butterfly-bush (2\%). Forbs were rarely consumed (4\%).

\section{Species Composition of Deer Diets}

A total of 46 species, ( 20 forbs, 19 shrubs, and 7 grasses) were identified as eaten by white-tailed deer in this study. Species composition in deer diets are shown by grazing method (Fig. 2). In the rotational grazed area, $\mathbf{4 5}$ forage species were identified and shrubs were the dominant component (53\%). The major browse species used by white-tailed deer were cenizo (16\%), panalero [Schaefferia cuneifolia, A. Gray] (14\%) and guajillo (7\%). Forbs averaged $28 \%$ of diets. The most important forb species were Physalis viscosa, L. (5\%). sangre de drago [Jatropha dioica, Sessé] (3\%) and Malva spp. (3\%). Grasses comprised $19 \%$ of the diet, and the most important species were zacate toboso (9\%), alkali sacaton (3\%), and zacate buffel (3\%).

In the continuous grazed area, the diversity of deer diets were relatively lower (38 forage species). Deer diets were higher in shrubs, and lower in grasses and forbs than in the rotational grazed area (Fig. 2). Shrubs comprised $73 \%$ of deer diets. The

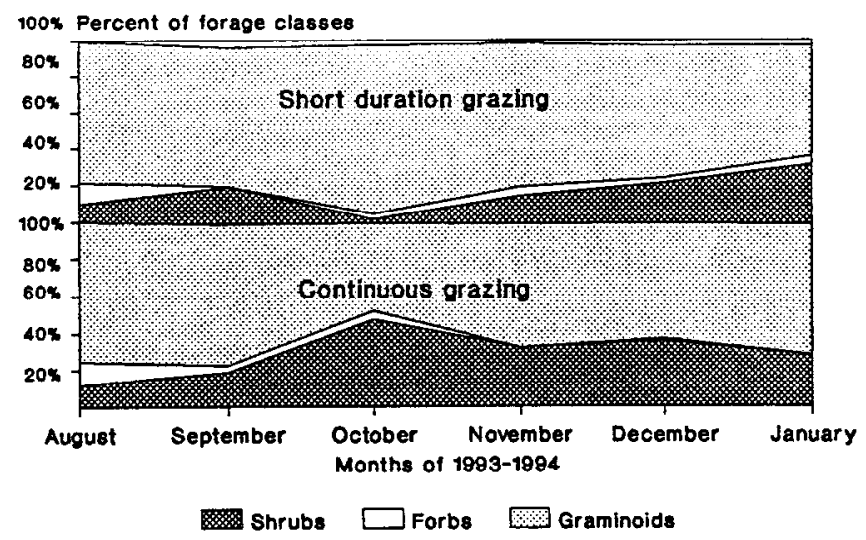

Fig. 2. Percent of forage classes in the diet of deer in a rotationally grazed and a continuously grazed area. 
Table 1. Botanical composition of rotational grazed (RG) and continuous grazed (CG) areas, diets of cattle and white-tailed deer in each area, and calculated relative preferences.

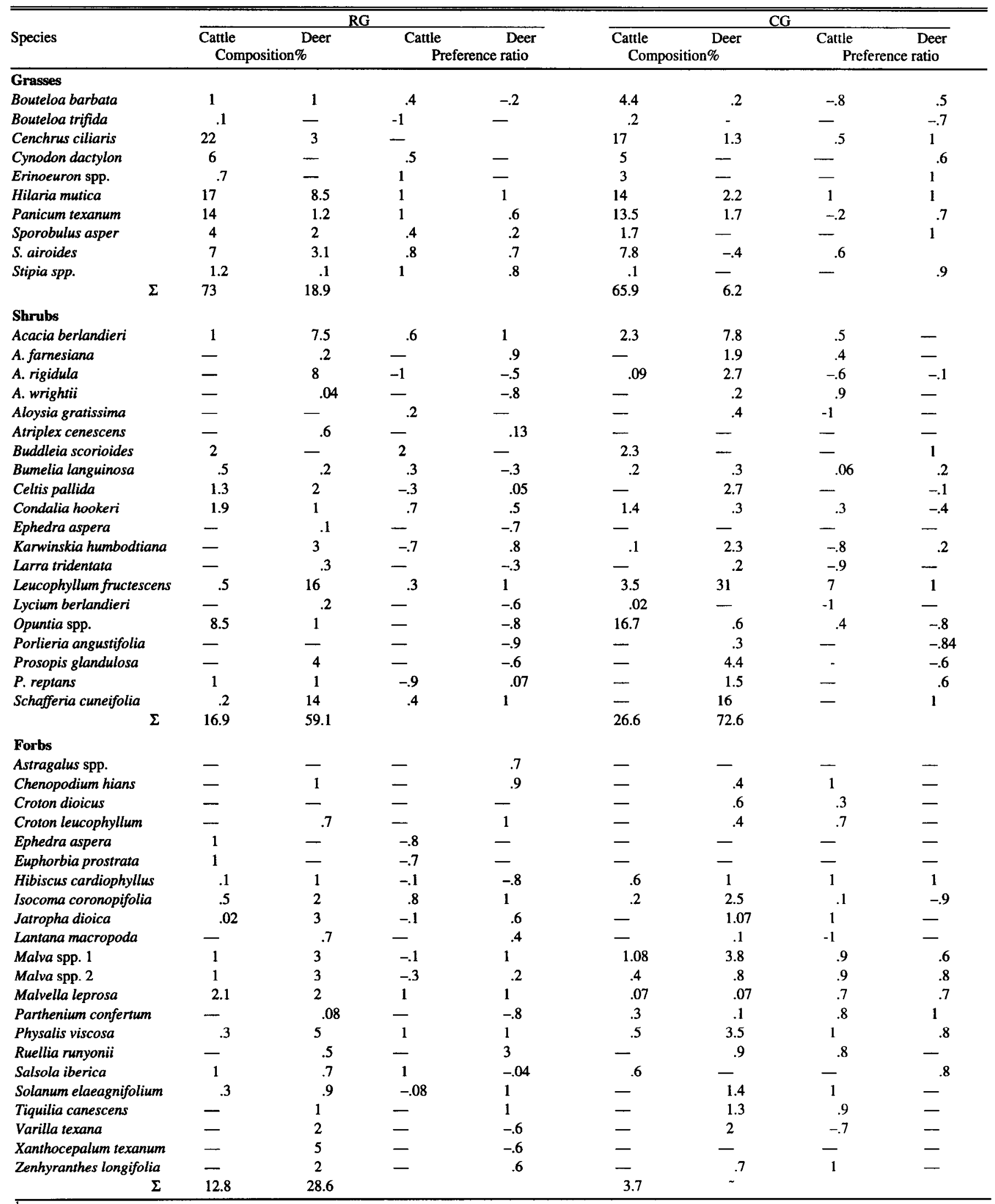

Botanical composition (\%), 2 preference ratio, ((-) not found in the diet or in the vegetation) 
major browse species were cenizo (31\%), panalero (16\%) and guajillo (8\%). Forbs were the second most abundant plant class (21\%). Malva spp., Physalis viscosa, L. (4\%), and Isocoma coronopifolia, (Gay) Greene (2\%) were the most important forbs. Grasses composed only the $6 \%$ of the deer diet. Zacate toboso, panizo texano, and zacate buffel were the most consumed grass species with $2 \%, 2 \%$, and $1 \%$ respectively.

\section{Preference Indices}

Grasses were the preferred forage class by cattle in both areas, and zacate toboso was the most preferred species. The shrub escobilla butterfly-bush was the second most preferred species by cattle. However, deer preferred forbs in the rotational grazed area, and forbs and grasses in the continuous grazed area. One grass, zacate toboso, was the most preferred species by deer in both areas (Table 1).

\section{Dietary overlap}

Of the 55 taxa identified in the collective diets of cattle and white-tailed deer in the 2 experimental areas, 27 were used in common. Dietary overlap in the rotational grazed area $(23 \%)$ was higher $(\mathrm{P}<0.05)$ than in the continuous grazed area $(15 \%)$ (Fig. 3). Fluctuations were inconsistent during the 6 month period between the 2 experimental areas (Fig. 3). Regarding the 6 month basis, overlap in the rotational grazed area ranged from $17 \%$ to $36 \%$. Diet similarity of cattle and white-tailed deer were greatest during January in the rotational grazed area. January data indicated white-tailed deer and cattle both consumed zacate toboso, guajillo, zacate buffel, and Isocoma coropifolia, (Gay) Greene. During September and October, the dietary overlap was similar. Common use of zacate toboso, panizo texano, granjeno, and nopal formed more than the $50 \%$ of the total overlap. In the continuous grazed area, dietary overlap ranged from $7 \%$ to $21 \%$ (Fig. 3). Diets were most similar during August (18\%) and November (21\%). Common species were zacate buffel and alkali sacaton during November.

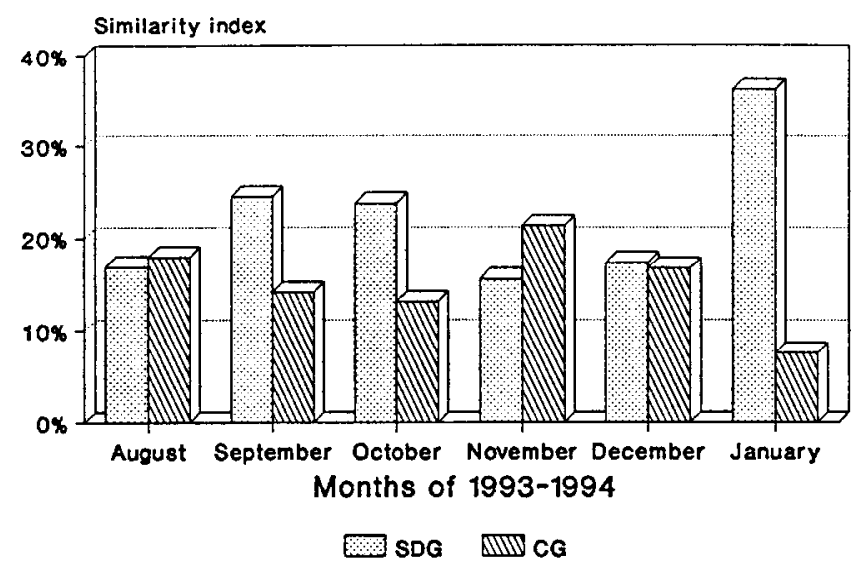

Fig. 3. Percent of dietary overlap between cattle and deer in the areas grazed differently.

\section{Discussion}

Cattle ate predominantly grasses in both grazing methods. Grasses have been reported to be the dominant forage class in cattle diets (Cook et al. 1963; Thetford et al. 1971; Galt et al. 1982). However, in this study the browse component of cattle diets was relatively high (23\%). This result may have local significance because browse can be important as a complementary dietary resource in the diet of cattle. Usually, local farmers, who have no interest in deer hunting, completely clear the shrub vegetation in order to plant grasses for cattle grazing. Releasing or planting some brush species in the pastures could result in ecological and economical benefices. Further investigation of agroforestry systems involving native woody species should be done in these areas.

The most commonly preferred species for cattle and deer was the grass zacate toboso. The phenological state of zacate toboso was not quantified but it was observed to be actively growing. Culms become coarse and relatively unpalatable with increasing maturity (Paulsen and Ares 1962). One important result is that preference for and the amount of zacate toboso consumed was higher in the rotational grazed area than in the continuous grazed area. In comparison with continuous grazing, rotational grazing appeared to improve the total usage of zacate toboso by maintaining palatable culms (Senock et al. 1993). The use of zacate toboso in the pastures under a rotational grazing system can be recommended for the common production of cattle and whitetailed deer in this region.

Thirty-four plant species are composed in the diet of cattle in the present study. A total of 27 plant species were found in the rumen forage samples from cattle on mesquite and mesquite-free desert rangeland neat Tucson, Arizona (Galt et al. 1982). However at the La Michilia Durango, Mexico cattle consumed 84 plant species (Morales cited by Gallina 1993). Differences in the diversity of the botanical composition of the pastures may be the cause of this difference. Deer diet was more diverse than cattle diets (46 plant species). Deer can exercise a higher degree of selectivity than cattle because of the smaller mouth size and body size (Hanley 1982).

The major browse species used by white-tailed deer in both grazing methods were in order of major contribution: cenizo, panalero, and guajillo. In contrast to our results, chaparro prieto was the major component of the diet of white-tailed deer in 3 pastures close to our area (Quintanilla 1989). In the present study, the proportion of chaparro prieto in the diet was less than in the forage on the other, indicating selection against this species.

The diversity of diets was lower in the continuous grazed area. Plant diversity was greater in the rotational grazed area. In south Texas rotational grade promoted greater herbaceous species richness, diminished plant litter accumulation, and increased forb cover in comparison with deferred rotation grazing (Wilkins and Wendell 1992).

Our results contrast south Texas, cattle use of vegetation types was more uniform under rotation grazing than continuous grazing (DeYoung et al. 1988). Difference in plant diversity between the pastures before the implementation of the grazing systems and differences in the management of the continuous grazed pastures may be the reason for different results between these experiments. 
Dietary overlap was significantly higher in the rotation grazed area than in the continuous grazed area. Cattle and deer share in this pasture more grass and forbs species in the rotational grazed area. During January the relatively high similarity index determined in the rotational grazed area would indicate minimal competition. However, dietary overlap is not sufficient evidence for competition (Colwell and Futuyma, 1971), and consequences of overlap depend upon availability of the resource. The reason for this difference may be the presence during January in the rotational grazing of plants with a higher proportion of cells content. In January in the rotational grazed area deer consumed the highest amount of grasses of the whole study. In contrast, in the continuous grazed area during the same month deer did not select any grasses.

\section{Conclusions}

The results of this study support the observation that cattle prefer grasses and deer prefer browse and forbs. However on Chaparral-mixed grass range under both continuous grazing and rotational grazing some species of different plant groups like prickly pear in the diet of cattle or zacate toboso in the diet of deer could be very important components in the diets of ruminants with different foraging strategies. The higher plant diversity within the rotational grazing area was responsible for the higher dietary diversity for both ruminants. Our results suggest that the use of zacate toboso in the pastures under the rotational grazing method can be recommended for common production of cattle and white-tailed deer on a shrub mixed grass savanna of the Rio Grande Plains.

\section{Literature Cited}

Arnold, L.A., Jr. and D.L. Drawe. 1979. Seasonal food habits of whitetailed deer in the South Texas Plains. J. Range Manage. 32:175-178.

Canfield, R.H. 1941. Application of the line interception method in sampling range vegetation. J. Forest. 39:388-394.

Chamrad, A.D. and T.W. Box. 1968. Food habits of white-tailed deer in south Texas. J. Range Manage. 21:158-164.

Cohen, W.D., D.L. Drawe, F.C. Bryant, and L.C. Bradley. 1989a. Observations on white-tailed deer in response to livestock grazing in south Texas. J. Range Manage. 42:361-365.

Cohen, W.D., D.L. Drawe, F.C. Bryant, and L.C. Bradley. 1989b. Day-time activity of white-tailed deer in response of short-duration and continuous grazing. The Southwestern Natur. 34:428-431.

Colwell, R.K. and D.J. Futuyma. 1971. On the measurements of niche breadth and overlap. Ecol. 52:567-576.

Cook, C.W., J.T. Blake, and J.W. Call. 1963. Use of esophageal fistulated cannulae for collecting forage samples from both sheep and cattle grazing in common. J. Anim. Sci. 22:579-581.

DeYoung, C.A., Jr., A. Garza, T.F. Kohl, and S.L. Beasom. 1988. Site preference by cattle under short-duration and continuous grazing management. Texas J. Agr. Nat. Resource. 2:35-36.

Davis, R.B. and C.K. Winkler. 1968. Brush vs. cleared range as deer habitat in southern Texas. J. Wildl. Manage. 32:321-329.

Drawe, D.L. 1968. Mid-summer diet of deer on the Welder Wildlife Refuge. J. Range Manage. 21:164-166.

Everitt, J.H. and D.L. Drawe. 1974. Spring food habits of white-tailed deer in the South Texas Plains. J. Range Manage. 27:15-20.

Hanley, Thomas A. 1982. The nutritional basis for food selection by ungulates. J. Range Manage. 35:146-151.
Galt, H.D., B. Theurer, and S. Clark Martin. 1982. Botanical composition of steer diets on mesquite and mesquite-free desert grassland. J. Range Manage. 35:320-325.

Gallina, S. 1993. White-tailed deer and cattle diets at La Michilia, Durango, Mexico. J. Range Manage. 46:487-492.

Oosting, H.J. 1956. The study of plant communities. W.H. Freeman and Co., San Francisco, Calif.

Paulsen, H.A. and F.N. Ares. 1962. Grazing values and management of black grama and tobosa grassland and associated shrub ranges of the southwest. USDA Tech. Bull. 1270.

Quintanilla, G.J.B. 1989. Determinación de la composición botánica de la dieta seleccionada por el venado cola blanca (Odocoileus virginianus texanus) en el norte del estado de Nuevo León. Master Thesis., Univ. of Nuevo León. Marin, N.L. Mexico.

Savory, A. and S.D. Parsons. 1980. The Savory grazing method. Rangelands 2:234-237.

Senock, R.S., D.M. Anderson, L.W. Murray, and G.B. Donart. 1993. Tobosa tiller defoliation patterns under rotational and continuous stocking. J. Range Manage. 46:500-505.

Sparks, D.R. and J.L. Malechek. 1968. Estimating percentage dry weight in diets using a microscopic technique. J. Range Manage. 21:264-265.

Taylor, C.A., Jr., M.M. Kothmann, L.B. Merrill, and D. Elledge. 1980. Diet selection by cattle under high-intensity, low frequency, short-duration, and Merrill grazing systems. J. Range Manage. 33:428-434.

Thetford, F.O., R.D. Piper, and A.B. Nelson. 1971. Botanical and chemical composition of cattle and sheep diets on pinyon-juniper grassland range. J. Range Manage. 24:425-430.

Wilkins, R.N. and G.S. Wendell. 1992. Bobwhite habitat under short duration and deferred-rotation grazing. J. Range Manage. 45:549-553. 